\title{
Knowledge and Attitudes Regarding Pain Management among ICU Nurse's
}

\author{
Yara Olimat ${ }^{1}$, Mohammad Albashtawy ${ }^{2}$, Ibrahim Ayasrah ${ }^{3}$, Jamal Qaddumi $^{4}$, Shereen Hamadneh ${ }^{5}$, \\ Ayman Bani Salameh ${ }^{6}$, Abdullah Alkhawaldeh ${ }^{7}$ \\ ${ }^{1} R N$, Istishari Hospital, Amman, Master Student, Critical Care Nursing, Princess Salma Faculty of Nursing, AL \\ al-Bayt University, Mafraq, Jordan, ${ }^{2}$ Professor, Princess Salma Faculty of Nursing, AL al-Bayt University, Mafraq, \\ Jordan, ${ }^{3}$ Assistance Professor, Faculty of Nursing, Jerash University, Jerash, Jordan, ${ }^{4}$ Associate Professor, Faculty \\ of Medicine and Health Sciences, An-Najah National University, Nablus-Palestine, ${ }^{5}$ Associate Professor, Princess \\ Salma Faculty of Nursing, AL al-Bayt University, Mafraq, Jordan, ${ }^{6}$ Assistance Professor, Faculty of Nursing, \\ Alzaytoonah university of Jordan, Amman, Jordan, ${ }^{7}$ Assistance Professor, Princess Salma Faculty of Nursing, AL \\ al-Bayt University, Mafraq, Jordan
}

\begin{abstract}
Pain management is an integral parts of nursing care and is one of the most important patient rights. This short review is intended to examine the knowledge and attitudes regarding pain management among ICU nurse's. This paper is used the electronic searches:google scholar, PubMed, CINAHL and World Health Organization (WHO).Nurses had good knowledge and a lower level of attitude towards pain management. However,the nurse's insufficient knowledge of pain management may be due many factors. Continuing education program should be conducted for nurses regarding pain and its management. Future studies are needed on the knowledge and attitude regarding pain management.
\end{abstract}

Keywords: Critical Care Nurses; Pain Management; Knowledge; Attitude.

\section{Introduction}

Pain is defined as an "unpleasant sensory and emotional experience correlating with actual or potential tissue damage ${ }^{(1)}$. Pain is one among the preeminent reasons bringing people to hospitals, and it is a common symptom for several cases inside medical care units ${ }^{(2)}$.

Pain is a subjective psychological and physiological experience, and accurate pain assessment and therefore the implementation of effective interventions are vital for successful pain management ${ }^{(3)}$. It is a modified through physiological, psychological and environmental

\section{Corresponding Author:}

\section{Abdullah Alkhawaldeh,}

$\mathrm{PhD}$, Assistance Professor, Princess Salma Faculty of

Nursing, AL al-Bayt University, Mafraq, Jordan.

Email:dr-abd@aabu.edu.jo

abdo_752012@yahoo.com factors such as past events, culture, diagnosis, coping strategies, fear and anxiety ${ }^{(4)}$.

Pain is a stressful experience. Many studies reported that about $55 \%$ to $78.6 \%$ of in patient's experience moderate to severe pain. In spite of training courses, application strategies, and multidisciplinary pain management teams, there are still problems associated with pain management ${ }^{(5)}$.

Pain can be managed through a multi-disciplinary team effort ${ }^{(6,7)}$. In their professional capacity as part of a healthcare team, nurses play an important role in relieving pain and improve the patient comfort ${ }^{(8)}$. The approach of the nursing staff toward pain management is important for relieving and reducing pain ${ }^{(9)}$. In all stages of pain starting with diagnosis a nurse is one of the most important members of a healthcare team and puts the most effort into action. Thus, the ability of nurses to appropriately assess pain in order to eliminate it is critical for effective pain management ${ }^{(10,11)}$. It is vitally 
important for ICU nurses to have the knowledge about pharmacological and non-pharmacological interventions used in pain management.

Pain management is serious aspect in health care, all healthcare professionals have to eliminate pain and suffering when possible, it must be the main goal for them because ineffective pain management can affect patients' psychological, physiologic, and financial status $^{(12)}$, causing more suffering, slower recovery ${ }^{(13)}$.

This short review is intended to examine the knowledge and attitudes regarding pain management among ICU nurse's.

\section{Method}

Search methods: The electronic searching was conducted in some different databases: Google scholar, PubMed, CINAHAL, and World Health Organization (WHO), using the key search terms: "Critical care nurses"; "Pain management"; "Knowledge"; "Attitude".

The studies published within the period 20072020, in English language, and focused on the nurse's knowledge and attitude regarding pain management were included in the paper.

Search outcome: Searching of literature yield 50 studies for review, 15 excluded when reviewed the title, 20when reading the abstract and 15 studies met the inclusion criteria.

\section{Discussion}

Aydede et al., in (2017) assess knowledge and attitude towards pain management among nurses, the researcher reported that the nurses had good knowledge and a lower level of attitude towards pain management than those reported in other studies, however, the situation requires various educational initiatives and quality improvement that can enhance the nurse 's knowledge and behavior in the field of pain management ${ }^{(1)}$.

While, Issa et al. in (2017) examined the impact of an educational program on the knowledge and attitude about pain assessment and management among critical care nurses. The researchers found a significant improvement in knowledge and attitudes about pain assessment and management among ICU nurses, it was evident after delivering pain management education program. Deficiencies and preconception in pain assessment and management can be improved through implementing pain management educational programs ${ }^{(2)}$.

The pain management service's roles are described in the context that a person's experience of pain is the result of biological, psychological and social factors ${ }^{(3)}$. Regarding the knowledge of pain management among nurses, there are a significant difference between the general knowledge relating to pain management using pharmacological and non-pharmacological methods. There are statistically significant, positive, and strong correlations between the nurse's knowledge about general knowledge on pain and knowledge about pharmacological and non-pharmacological methods $(8,11)$.

The Turkish study was conducted at a university hospital to examine thenurse's knowledge level toward pain management procedures that could be used for the care of patients in pain. this study reported that medicalsurgical nurseshad the lowest level of knowledge regarding pain control methods compared with ICU nurses who record the highest level of knowledge ${ }^{(14)}$.

The nurse's insufficient knowledge of pain management may be due to curricular gaps during training; insufficient clinical supervision, study days, and workshops for nursesand the negative attitude of nurses as the new information learned at workshops was not easily applied in clinical practice ${ }^{(15)}$.

A recent study aimed to assess the effectiveness of pain management education program among nurses working in ICU. The study found that the program was effective in increasing the knowledge level and attitudes of ICU nurses to be more positive toward pain management the $\mathrm{e}^{(16) \text {. }}$

\section{Conclusion}

Using educational program and interactive methods can be associated with an increased level of knowledge and attitudes regarding pain management among ICU nurse's. This can help nurses in the future to improve the quality of services for patients through better evaluation and treatment. 
The nurses received low level for pain beliefs, which remained the same after education. This suggests that the nurses may use non pharmacological methods in pain management, such as visualization and distraction in addition to pharmacological methods. Using no pharmacological options may have a positive effect on patients and help them participate in pain control.

Conflict of Interest: No conflict of interest.

Ethical Clearance: Taken fromPrincess Salma Faculty of Nursing, AL al-Bayt University ethical committee.

Source of Funding: Self.

\section{References}

1. Aydede, M.Defending the IASP definition of pain. The Monist 2017; 100:439-464.

2. Issa, M. R., Awajeh, A. M., \&Khraisat, F. S. Knowledge and attitude about pain and pain management among critical care nurses in a tertiary hospital. J Intensive Crit Care 2017; 3.

3. Cox, F. (2010). Basic principles of pain management: assessment and intervention. Nursing Standard (through 2013) 2010; 25:36.

4. Republic of Rwanda. Pain management guideline. Ministry of Health 2012;Kigali, Rwanda.

5. Benimana, O. Knowledge, attitudes, practices and challenges faced by nurses in pain management among surgical patients, in one Referral Hospital in Rwanda (Doctoral dissertation, University of Rwanda) 2017.

6. ÖZVEREN, A. G. H., \&Hülya, U. Ç. A. R.Öğrenci hemşirelerin ağrıkontrolündekullanılan farmakolojik olmayan bazıyöntemlere ilişkin bilgileri. Hacettepe Üniversitesi HemşirelikFakültesiDergisi 2009; 16:59-72.

7. Unver, S., Ozkan, Z. K., Avcibasi, I. M., \&Digin, F. B. Determining the postoperative pain management interventions of nursing students/Hemsirelik ogrencilerininameliyat sonrasi agriyonetimineiliskin girisimlerinin degerlendirilmesi. Journal of Education and
Research in Nursing 2016; 13:146-151.

8. Midilli, T. S., Eşer, İ., \&Yücel, Ş. Cerrahi Kliniklerinde Çalışan Hemşirelerin AğrıYönetiminde Nonfarmakolojik Yöntemleri Kullanma DurumlarıveEtkileyenFaktörler. ACU SağlıkBilDerg 2019; 10:60-6.

9. Yüceer S. Yüceer, S. Ameliyat sonras1 ağrıönetimindehemşirelikyaklaşımları. Journal of Clinical and Experimental Investigations 2011; 2:474-478.

10. DEMIR, Y., USTA, Y. Y., Yasemin, İ. N. C. E., GEL, K. T., \& AKI, M. K. Hemşirelerin ağrıönetimiileilgilibilgi, davranışveklinik karar vermedurumlarınınbelirlenmesi. Çağdaş Tıp Dergisi 2012; 2: 162-172.

11. Malak, A., \&Beji, N. K. (2015). Kronik PelvikAğrıveHemşirelikYaklaşımı. Okmeydanı Tıp Dergisi, 31(2), 92-7.

12. Li, D., Miaskowski, C., Burkhardt, D., \& Puntillo, K. Evaluations of physiologic reactivity and reflexive behaviors during noxious procedures in sedated critically ill patients. Journal of Critical Care 2009; 24:472-e9.

13. Panteli, V., \&Patistea, E. Assessing patients' satisfaction and intensity of pain as outcomes in the management of cancer-related pain. European Journal of Oncology Nursing 2007; 11:424-433.

14. Akbaş, M., \&Öztunç, G. Examination of knowledge about and nursing interventions for the care of patients in pain of nurses who work at Cukurova University medical faculty Balcali hospital. Pain management nursing 2008; 9:88-95.

15. Aziato, L., \&Adejumo, O. Determinants of nurses' knowledge gap on pain management in Ghana. Nurse Education in Practice 2014; 14:195-199.?

16. Issa, M. R., Awajeh, A. M., Khraisat, F. S., Rasheed, A. M., Amirah, M. F., Hussain, A., \&Alharthy, A. Impact of an Educational Program on the Knowledge and Attitude About Pain Assessment and Management Among Critical Care Nurses. Dimensions of Critical Care Nursing 2019; 38:271277. 